\title{
UTILIZAÇÃO DE JOGOS DIGITAIS COMO ESTRATÉGIA DIDÁTICO-PEDAGÓGICA: UMA EXPERIÊNCIA COM ALUNOS DE ENSINO MÉDIO NA DISCIPLINA DE BIOLOGIA
}

\author{
USE OF DIGITAL GAMES AS DIDACTIC-PEDAGOGICAL STRATEGY: AN \\ EXPERIENCE WITH HIGH SCHOOL STUDENTS IN THE DISCIPLINE OF \\ BIOLOGY
}

DOI: http://dx.doi.org/10.23926/RPD.2526-2149.2019.v4.n1.p255-274.id429

\section{Marcelo Alexandre Bruno \\ Doutor em Oceanografia Biológica pela Universidade Federal do Rio Grande (FURG) \\ Professor Instituto Federal do Mato Grosso (IFMT) marcelo.bruno@alf.ifmt.edu. $\underline{b r}$}

\section{Regina Barwaldt \\ Doutora em Informática na \\ Educação (UFRGS) \\ reginabarwaldt@furg.br}

\section{Sueli Aparecida}

Thomazine

Especialista em Tecnologias da Informação e

Comunicação na Educação (FURG)

suthomazine@gmail.com
Resumo: O estudo objetiva-se a construção de jogos usando a linguagem de programação Scratch, a partir da problematização e dúvidas dos alunos na disciplina de Biologia. A pesquisa envolveu alunos do $2^{\circ}$ ano do ensino médio. Duas oficinas foram realizadas no laboratório de informática do IFMT campus Alta Floresta para que os alunos pudessem construir os jogos digitais. Para a análise de dados foram considerados os registros da oficina de apresentação e ambientação na linguagem e um questionário como instrumento de avaliação da atividade. A partir das expectativas iniciais, o presente trabalho trouxe uma experiência importante para reafirmar a necessidade de um ensino modificado, pois ampliaram-se as possibilidades de aprender pelo interesse e motivação na construção dos jogos, usando as tecnologias da informação na comunicação, proporcionando o controle e a autonomia no processo de aprendizagem.

Palavras-chave: Biologia; tecnologias; jogos; ensino; aprendizagem.

\begin{abstract}
The study aims to construct games using the programming language Scratch, from the problematization and doubts of the students in the discipline of Biology. The survey involved students in the second year of high school. Two workshops were held in the IFMT campus Alta Floresta computer lab so students could build digital games. For the analysis of the data were considered the records of the workshop of presentation and setting in the language and a questionnaire as an instrument of evaluation of the activity. From the initial expectations, it is assumed that the present work has brought an important experience to reaffirm the need for a modified teaching since the possibilities of learning by the interest and motivation in the construction of the games using technologies of the information in the communication that provided the control and autonomy in the learning process.
\end{abstract}

Keywords: Biology; technology; games; teaching; learning. 


\section{INTRODUÇÃO}

A sociedade globalizada, de forma direta ou indiretamente, está digital e é irreversível. Esse processo, como toda mudança, vem sendo gradual, porém em velocidade e quantidades surpreendentes, uma revolução que pode ser comparada ao impacto dos tipos móveis/prensa, no advento da imprensa (século XV), abrangendo, sem exceção, os diversos segmentos da sociedade contemporânea e transformando todos os tipos de relações: sociais, culturais, econômicas e de produção, etc. A educação também está inserida nesse contexto e exigindo outras posturas e linguagens no processo de ensino e aprendizagem, ou seja, os sujeitos (educadores e educandos) compreenderem a necessidade adquirir novas competências e de traçar novas estratégias e práticas para se aproximar dos "novos alunos" (COLL; MONEREO, 2010, p.18-21).

Esses "novos" alunos são denominados por Prensky (2001) de "nativos digitais", frutos da alta conectividade na sociedade contemporânea. Esses jovens têm essa proximidade com as mídias e têm delineado um perfil/identidade como parte da cultura digital, porém cabe ao professor auxiliar, motivar, criar condições em que as TIC's possam e devam ser usadas na construção do conhecimento e na sua formação profissional.

A busca por novos paradigmas na educação, assim como as mudanças e estratégias apoiadas nas ferramentas digitais, devem acontecer de modo a envolver todos os sujeitos inseridos no processo, especialmente, o aluno e professor, numa postura favorável para renovar as competências e, principalmente, habilidades e autonomia frente às TIC's. O modelo de ensino tradicional, no qual predominam posições hierarquizadas, protagonizando o professor como o único "dono do saber" em sala de aula, está sendo questionado, pois não contempla o perfil desses alunos "nascidos digital”. As Tecnologias da Informação e Comunicação (TIC's) trazem para a reflexão e discussão a urgente necessidade de repensar modelos tradicionais de ensino. Para Fagundes (COMO ENTRA A CULTURA DIGITAL NA ESCOLA, 2011), as metodologias educacionais estão ineficientes para formar professores, tendo em vista as novas competências e habilidades do mundo tecnológico.

Neste trabalho objetiva-se refletir a inserção das tecnologias na sala de aula através da elaboração e construção de jogos educacionais digitais pelos alunos, procurando relacionar os conceitos de biologia do ensino médio à ferramenta de programação Scratch, integrados pela mediação e intervenção entre professor e alunos.

Este artigo está organizado em seções: a) inicialmente há a apresentação do artigo na introdução; b) após, segue um breve texto reflexivo fundamentado nas percepções dos autores 
que apoiaram as compreensões sobre as TIC's na Educação e o professor enquanto mediador pedagógico; c) discorre-se sobre jogos e aprendizagem com referenciais teóricos que orientam as definições de jogos digitais na escola e traz a construção de jogos digitais (Scratch) como estratégia metodológica no ensino e aprendizagem da Biologia; d) na terceira seção, destacamse a Metodologia Educativa (ME) e a metodologia da pesquisa assumida na experiência de aplicação do PAE; e) na quarta seção, mostra-se a análise de dados e resultados da pesquisa; f) segue, por último, das considerações finais acerca do trabalho, finalizando o artigo com as referências bibliográficas.

\section{AS TECNOLOGIAS NA EDUCAÇÃO E OS JOGOS NA APRENDIZAGEM}

$\mathrm{Na}$ educação, apesar de todos os recursos e ferramentas digitais que compõem esse cenário contemporâneo/digital, deve-se considerar outras questões e realidades que inviabilizam assumir metodologias apoiadas nas ferramentas digitais somente. O papel do professor é essencial no processo de ensino e aprendizagem. Entretanto, esse papel, apesar de preponderante, também exige mudanças frente à inserção das TIC's em salas de aula, no processo de ensino e aprendizagem, assim como destaca Demo:

Embora seja um pouco apressado dizer que pedagogia vem antes da tecnologia (vêm
juntas, também porque tecnologia não é apenas meio), é certo que o desafio formativo
é a razão maior de ser. Nesse sentido, sem pedagogia, nada feito. Na verdade, trata-se
de envolver os estudantes no processo de aprendizagem, fomentar habilidades de
aprendizagens autônoma, embora preferencialmente coletiva, desenvolver habilidade
de construção de conhecimento, motivar aprendizagens sem fim (DEMO, 2009, p.37).

No presente trabalho optou-se por buscar a metodologia de projetos sob uma ótica construtivista, apostando no protagonismo de nossos jovens na constituição de sua identidade escolar e de sua formação profissional. Construtivista por optar pela construção do conhecimento, partindo da igualdade na ação de aprender, professor e alunos diante de um problema mobilizando conhecimentos prévios e estimulando a criação de novos esquemas de pensamento para resolução de dúvidas (FAGUNDES; SATO; LAURINO, 1999 p. 31).

No ensino da Biologia, o professor, em geral, usa de analogias para explicar o funcionamento dos sistemas vivos e se deparam com alunos que nascem imersos nas tecnologias, porém não as percebe como ferramentas que podem ser usadas a seu favor, na construção do seu processo de formação profissional e na construção do conhecimento. Nesses casos, as TIC’s são “enxergadas” pelos nativos e pela comunidade (especialmente os pais, pela escola/coordenação pedagógica, profissionais e até mesmo legisladores) como instrumentos de lazer. Assim, urge a necessidade de socializar e insistir na inserção das TIC's no processo de 
ensino e aprendizagem, ou seja, diminuir a distância entre a teoria, conceitos e aplicações na vida prática, incluindo as TIC's.

A escola está aberta para essas novidades tecnológicas digitais, porém esbarram numa série de dificuldades, como falta de recursos e a existência de equipamentos eletrônicos e redes de conectividade insuficientes para atender as demandas educacionais para adotar as metodologias apoiadas nas TIC's.

Ainda sob essa ótica, os profissionais que atuam na educação, desvalorizados e desmotivados por diversos aspectos econômicos e sociais, nem sempre estão disponíveis e/ou abertos para essas novas propostas que exigem mudanças. Assim, as mudanças que deveriam acontecer dentro de cada profissional e depois se estender à escola e, consequentemente, para a sala de aula, flutuam no mar de incertezas entre o "ter que fazer" (porque as TIC's têm que fazer parte do processo) e outras questões do "como fazer". Isso pode ser explicado pelo fato de os sujeitos terem medo do "novo", das mudanças e até mesmo do enfrentamento com esses alunos "nativos digitais" que parecem saber tudo sobre as ferramentas digitais. Os nativos cresceram sob essa tecnologia digital, enquanto as gerações anteriores, em especial os professores, estão migrando para essas tecnologias (imigrantes digitais). Importante enfatizar que o que muda é o modelo do pensamento (PRENSKY, 2001).

Todo esse dilema exige do professor uma postura de humildade, ou seja, de desconstrução, isto é, reconstruir-se adquirindo competências e habilidades de autonomia frente às TIC's, revitalizando-se, como nos mostra Demo ao afirmar:

[...] manter sobre as tecnologias o olhar arguto crítico e autocrítico, não de resistência, mas de quem sabe pensar. Cabe a ele, em grande parte, retirar do cenário o tom de confronto com as tecnologias e seus expertos, substituindo pela atitude de parceria [...] Na prática, as novas tecnologias não destronaram o professor; ao invés, encontraram seu lugar mais adequado, realçando a nobreza da função [...] No fundo, as tecnologias rendem-se à maior tecnologia jamais inventada na espécie humana: aprender bem (DEMO, 2009, p. 110).

Em relação ao educar, busca-se o sentido de que educar se constitui num processo onde os sujeitos convivem e transformam a si mesmos nesse espaço de convivência. Maturana (1995) ressalta que esse processo dura a vida toda, em todo o tempo e de maneira recíproca. Educandos e educadores confirmam seu viver nesse "mundo" chamado educação, vivendo no "educar", e enfoca especialmente os jovens, quando diz:

Na juventude, experimenta-se a validade desse mundo de convivência na aceitação e no respeito pelo outro a partir da aceitação e do respeito por si mesmo, no começo de uma vida adulta social e individualmente responsável (MATURANA, 1995). 
O aceitar-se e respeitar-se ganha centralidade na visão do autor, pois partindo dessa aceitação nesse espaço é que o educando e o educador vivenciam o educar, pois

educar é um processo de transformação na convivência de todos os atores envolvidos e, se queremos que nossos meninos e meninas cresçam como seres autônomos no respeito por si mesmos e com consciência social, temos de conviver com eles respeitando-os e respeitando-nos na contínua criação de uma convivência na colaboração, a partir da confiança e do respeito mútuos (MATURANA; DÁVILA, 2006, p. 31).

No Projeto de Ação na Escola (PAE), partimos do pressuposto que aprender é conviver e que o "aprender se dá em conjunto" e, mais ainda, "no respeito pelo que sou", "naquilo que me diferencia do outro", passando assim a respeitar o semelhante no espaço de convivência. A aceitação de si e do outro garante a legitimidade e o fenômeno social e ainda demonstra que "aprender bem só pode ocorrer em ambientes em que o aluno se torna o centro das atenções e permanece ativo, envolvido, participativo" (MATURANA; DÁVILA, 2006, p. 31).

Neste estudo buscou-se articular os referenciais acima, supondo que os alunos imersos nas tecnologias (nativos) - buscando sua identidade e formação - e o professor - buscando novas formas de ensinar e aprender - num contexto colaborativo e de autoria como (co)construtores do processo de ensino e aprendizagem em Biologia, no ensino básico do nível médio.

\subsection{OS JOGOS E A APRENDIZAGEM}

Hoje, estamos diante de um "novo homem o homo game junto ao homo ludens", ou seja, o homem que joga e se diverte e está imerso nas tecnologias digitais (HUIZINGA, 2000). O maior objetivo ao construir jogos é motivar os sujeitos do processo de aprendizagem, a construir suas próprias ideias para solução de problemas. No entanto, a maioria das abordagens sobre os impactos das TIC's nos jovens (nascidos digitais), envolvendo jogos digitais, é direcionada para as questões sociais e emocionais, especialmente questões que lidam com a violência. Dessa maneira, os jogos digitais vêm carregados de certo preconceito, pois é comum obter-se relatos e atribuir-se comportamentos aos jovens relacionando-os a jogos digitais, principalmente àqueles com conteúdo de violência. Dessa forma, vários estudos demonstram que a sociedade em geral tem algumas reservas quanto à utilização de jogos digitais, desencadeando discussões como "proteção dos jovens em relação à sua exposição a determinados conteúdos (violência, sexo, homofobia, machismo, etc.)”. Para Lalueza e Camps (2010), essas afirmativas que relacionam os jogos digitais a condutas sociais de violência, assim como outros comportamentos de efeitos negativos, são contestadas em vários estudos demonstrando que 
[...] os videogames são narrativas que fazem parte da rede de significados de cultura e, por isso, não são autônomos na geração de valores. Pelo contrário, suas narrativas cobram significado em relação àquela gerada pelo restante das práticas sociais das quais participam os indivíduos. Mais uma vez, é o marco institucional no qual essas práticas ocorrem que se mostra relevante (LALUEZA; CAMPS, 2010, p. 56).

Assim, os docentes na era digital, além das questões com a educação, instituição, alunos e ferramentas digitais, ainda têm a preocupação de romper essas barreiras esclarecendo, junto aos responsáveis (família) e outros envolvidos, as possibilidades metodológicas das ferramentas no processo de ensino e aprendizagem. Os jogos podem ser ferramentas de aprendizagem eficientes, pois ao mesmo tempo trazem componentes instrucionais de diversão e motivação para facilitar o aprendizado, além de influenciar na sua capacidade cognitiva.

Nesse processo, além de todo quadro e (pre)conceito que existe sobre os jogos digitais, o grande desafio passa por aproximar a motivação dos alunos pelos jogos digitais que fazem parte do seu cotidiano ao percurso pedagógico que precisam realizar durante o ensino formal nas escolas.

Segundo Alves (2008) as pesquisas sobre os jogos eletrônicos, enquanto objeto da discussão na aprendizagem, surgem na década de 1980, divididos em dois grupos: a) o primeiro deles enfoca a distinção entre jogos eletrônicos e digitais, em função de duas ou três dimensões, afetando parâmetros como "jogabilidade", interatividade e realismo de cenas; b) o segundo grupo pertence aos jogos eletrônicos comerciais, afetando a imersão do jogador. Os jogos desse tipo não trazem explicitamente conteúdos pedagógicos.

Ao jogar, os alunos imergem em um mundo deslocado da realidade, onde experimentam desafios, despertam sua criatividade, participam e criam regras para modificação dessa realidade e solução de problemas.

Um jogo se torna educacional quando tem um embasamento pedagógico ou fundamentado em objetivos educacionais específicos. Os jogos educacionais com uso de softwares proporcionam uma abordagem autônoma, pois o jovem constrói estratégias para aprender por si só, interagindo com os componentes do software (TAROUCO et al., 2004). Esses jogos educacionais apresentam atividades práticas que têm por objetivo o lazer e diversão e, para Falkenbach (2006), além da exploração livre, o componente lúdico estimula o aluno ao aprendizado.

Dentre os tipos de jogos, segundo Lucchese e Ribeiro (2009), destacam-se: a) jogos de estratégia: cujo enfoque são as habilidades do usuário, usando pensamento para solucionar problemas; b) jogos de ação: direcionando para os reflexos, na coordenação de movimentos e rapidez no pensamento para reação às situações inesperadas; c) jogos lógicos: exigem 
manipulação de conceitos e estabelecem etapas que podem ser contra o tempo ou de pontuação; d) jogos de aventura: pressupõem um ambiente onde o jogador controla e explora o ambiente; e) jogos interativos: os jogadores devem estar conectados online, dependem da web e são usados para simulações em que o jogador depende da interação com outro jogador; f) jogos de treino e prática, importantes para revisão de conteúdos que dependem de memorização de conceitos e regras; g) jogos de adivinhação: o jogador é estimulado a responder perguntas e buscar pontuação, ranking. Dentre esses destacam-se os jogos de aprender, cujos conhecimentos são denominados como atividades didáticas digitais. Esses jogos podem ser do tipo quiz com perguntas e respostas para avançar entre as etapas.

Nesse sentido, Lucchese e Ribeiro (2009) criaram categorias para a análise dos tipos de jogos, apoiados em outros autores, como Juul (1998) e Battaiola (2000), classificando e conceituando os tipos de jogos: 1) estratégia: depende das decisões do jogador, envolve habilidades cognitivas; 2) simuladores: imersão do jogador para interação com ambientes complexos; 3) aventura: desafios com enigmas onde existe a combinação entre raciocínio e habilidades psicomotoras; 4) infantil: quebra-cabeças e estórias; 5) passatempo: quebracabeça com soluções rápidas e com pouco enredo; 6) RPG $\mathbf{P}^{\mathbf{1}}$ : versões digitais que mesclam tabuleiro e desafios em situações de interação; 7) esportivos: assim como jogos de futebol e basquete; 8) educacionais: podem ou não se enquadrar nos grupos anteriores, porém com objetivos didáticos e pedagógicos associados aos conceitos.

Juul (1998) propõe ainda que os jogos digitais devem possuir os seguintes critérios:

- regras e resultados: as ações do jogo estão vinculadas a um conjunto de regras formais com resultados bem definidos;

- metas e conflitos: chegar a um objetivo, no entanto este pode apresentar-se com metas contraditórias entre os jogadores;

- autossuficiente e independente: o jogo por si só não leva a um vencedor ou perdedor perdendo vinculação com fim ou objetivo, prazer de jogar apenas;

- ficção: pode ter um papel importante nos jogos digitais, realidade aumentada ou complexa.

Em relação aos estudos que buscam associar jogos e os conteúdos de Biologia, Santos et al. (2015) criaram o jogo bioquiz, um jogo de perguntas e respostas direcionado para alunos do ensino médio com base nas linguagens de programação HTML5, CSS e Javascript. Neste

\footnotetext{
${ }^{1}$ RPG sigla para Role-playing games, um tipo de jogo onde os jogadores assumem papel de personagens fictícios. 
estudo, o enfoque do jogo foi a Biologia celular. O design apresentou personagens (as organelas) que interagem com o jogador, motivando-o a buscar a resposta e estimulando o acerto e o erro. O jogador acessa sua pontuação e correção das respostas, possibilitando uma reavaliação ou (re)construção do seu conhecimento.

Enfocando o mesmo tipo de jogo (quiz), Silva e Faria (2012) elaboraram um jogo sobre os conhecimentos de membrana plasmática, desenvolvido no software Impress do LibreOffice. Nesse caso, o jogo apresenta uma sucessão de interfaces com perguntas e respostas, cujo erro remetia a um novo slide, propiciando relembrar os conceitos.

\section{Metodologia}

O trabalho foi desenvolvido com alunos voluntários do $2^{\circ}$ ano do ensino médio com faixa etária entre 15 e 17 anos. A atividade foi realizada em dois campi: 1) IFMT campus Alta Floresta: utilizou-se 20 (vinte) microcomputadores disponíveis no Laboratório de Informática da instituição, com acesso e conexão online da ferramenta para construção do jogo (Scratch); 2) IFMT campus avançado de Paranaíta: foram disponibilizados 20 (vinte) microcomputadores, porém devido à dificuldade de conexão (região de difícil acesso), instalou-se o software Scratch para a utilização da ferramenta offline.

Inicialmente, os alunos receberam a divulgação e o convite para a participação e horários das oficinas. Também foram divulgadas as duas datas de realização das oficinas, totalizando 35 alunos, envolvendo os alunos dos dois locais.

Para a construção dos jogos, fez-se necessária a escolha de um software, no qual fossem explícitas as estratégias de pensamento, associação com os conceitos de Biologia e programação desse pensamento para finalização em um jogo digital para o estudo da Biologia. Foram definidas etapas para associar a tecnologia utilizada (ferramenta de programação Scratch) ao ensino e aprendizagem, ou seja, uma sequência didática para o uso do Scratch no ensino e aprendizagem de conceitos de Biologia (Quadro 1).

Quadro 1 - Sequência didática com as etapas utilizadas no presente estudo

\begin{tabular}{|c|l|}
\hline Momentos pedagógicos & \multicolumn{1}{|c|}{ Ações de ensino e aprendizagem } \\
\hline Problematização & $\begin{array}{l}\text { Escolha do assunto, do problema ou situação que } \\
\text { pretende simular através da construção do jogo. }\end{array}$ \\
\hline
\end{tabular}




\begin{tabular}{|c|l|}
\hline Conhecendo a ferramenta (TIC) & $\begin{array}{l}\text { Escolher e definir tipo de jogo, personagem, } \\
\text { cenário, script, blocos. }\end{array}$ \\
\hline Organização do conhecimento & Elaborar narrativa associando etapas anteriores. \\
\hline Testes & $\begin{array}{l}\text { Testar e ajustar recursivamente - o jogo alcançou } \\
\text { suas expectativas? }\end{array}$ \\
\hline Compartilhamento & Compartilhar seu projeto. \\
\hline
\end{tabular}

Fonte: Autor (2018)

As atividades foram realizadas em dois encontros de $4 \mathrm{~h} / \mathrm{a}$, totalizando $8 \mathrm{~h} / \mathrm{a}$. Na etapa inicial, os alunos foram estimulados a pensar sobre situações em que a biologia permeia o seu aprendizado. $\mathrm{Na}$ conversa inicial retomamos os assuntos que já haviam sido explicados no primeiro ano e no primeiro bimestre do segundo ano. Para que essa etapa fosse produtiva, estabelecemos uma conversa inicial com enfoque nos conceitos já discutidos previamente na disciplina e utilizamos a ferramenta padlet.com ${ }^{2}$, um compartilhador de conteúdos, para que os alunos relatassem seus projetos iniciais.

Posteriormente, com o objetivo de avaliar as oficinas de forma quantitativa e qualitativa, aplicou-se aos alunos um instrumento de avaliação (questionário online) construído no Google Forms $^{3}$, com 6 questões com opções de respostas abertas e optativas:

1) Qual assunto da biologia eu escolhi?

2) Por que eu escolhi esse assunto?

3) Como eu usei o Scratch para tentar encontrar uma solução? Faça uma breve descrição de como propôs uma solução para o problema.

4) Após as etapas de construção do objeto digital, acredito que:

( ) alcancei meu objetivo para entender o assuntos

( ) não alcancei meu objetivo

5) Justifique a escolha da resposta anterior.

6) Qual é a sua avaliação sobre a atividade e o que poderia melhorar?

Após as oficinas, foram realizadas análises quantitativas e qualitativas com os relatos do instrumento de pesquisa (formulário Google). Foram criadas categorias para análise e sumarização dos dados em gráficos. Para evitar a identificação dos alunos, utilizamos as iniciais de nomes fictícios.

\section{ANÁliSE dOS RESULTADOS E DISCUSSÕES}

2 Disponível em: www.padlet.com.

3 Disponível em: https://www.google.com/intl/pt br/forms/about/. 
Apenas 26 alunos dentre os participantes retornaram respostas. Provavelmente o baixo retorno ao questionário possa ter sido influenciado pela organização da atividade em oficinas de curta duração. Ao não concluir sua atividade com a criação dos jogos, os alunos podem ter interpretado que sua atividade incompleta não deveria ser relatada no questionário. Ao usar TIC's para aprender os alunos definiram o seu ritmo de aprendizagem que pode ou não ser maior do que o tempo de realização da oficina. Essa variável "tempo" para aprendizagem pode ter influenciado na taxa de resposta.

Na primeira etapa da oficina, os alunos foram questionados sobre qual assunto de suas dúvidas escolheria para criar o jogo. Dentre os assuntos escolhidos, predominou a genética, assunto atual do currículo. Os demais assuntos, por ordem de preferência, foram: ecologia, reprodução e histologia. Percebeu-se que os alunos manipularam os conceitos procurando criar jogos a partir da temática escolhida. Essa etapa pode ser definida como "escolha" do tipo de jogo. Representa uma etapa inicial em que o aluno traça suas estratégias de manipulação de conceitos.

A Figura 1 nos mostra a problematização da escolha dos assuntos, trazendo as respostas atribuídas para a questão de número um do questionário online, evidenciando que a maioria dos alunos optou pelo assunto: "genética". Assim, criou-se, a partir dessa definição, uma categoria geral, no entanto os alunos demonstraram possibilidades de assuntos como a "divisão celular" (aluno AC), "mitose" (aluno TLM), "leis de Mendell” (aluno MLCS), "quadrado de Punnett" (aluno MG), "tipos sanguíneos” (alunos GJ, MV e P). A partir desse momento, os alunos foram estimulados a definir situações-problema para definir os personagens, as regras, os objetivos dos jogos e os tipos de jogos. Essas escolhas justificaram-se pela complexidade, grau de dificuldade de manipulação de conceitos e abstração do assunto e ainda, provavelmente, pelo tema ser o assunto do momento nas aulas que antecederam a aplicação da oficina. 
Figura 1 - Etapa 1. Respostas à questão “qual assunto da biologia eu escolhi?” Etapa inicial de problematização e escolha dos assuntos

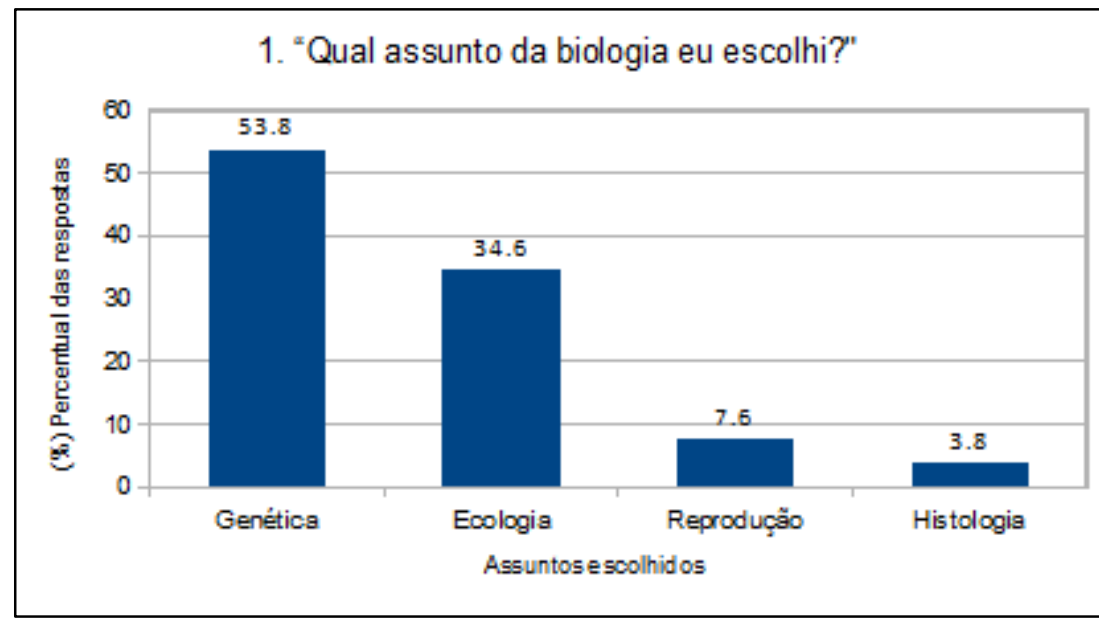

Fonte: $\mathrm{O}$ autor (2018)

Em relação às etapas de avaliação sugeridas por Prensky (2003) apud Savi et al. (2010), os alunos partem de suas dificuldades para definir "personagens", “ações", "objetivos", "regras", ou seja, essa etapa foi para a criação de "histórias/narrativas", o palco onde serão realizadas as ações do jogo e, dessa forma, também ações de aprendizagem.

$\mathrm{Na}$ questão 2, foram criadas categorias para sintetizar as respostas dos alunos participantes da oficina, observando-se que a metade dos participantes foram motivados por interesse, relevância e importância do assunto. Dentre os relatos sobre o interesse, o aluno HH destacou que há interesse pelas pessoas. $\mathrm{O}$ aluno relatou que escolheu construir um jogo de dinâmica populacional de peixes, simulando a relação presa/predador, na diferença dos tamanhos de peixes e na interação, em que um é alimento do outro. A "pesca” foi elencada por ser um assunto que vai ao encontro da atividade econômica da região, o ecoturismo, pescarias e turismo voltado para essa atividade.

O assunto "ecologia" também foi escolhido pelo aluno GCM, cujo tema desenvolvido foi "superpopulação" com destaque na interação presa/predador, assim como no relato anterior. No entanto os personagens escolhidos (leão, elefante, hipopótamo) não fazem parte do ecossistema local, mas o conceito de "regulação da população" por predação foi aplicado à criação do jogo. A aluna MSIS e seu grupo escolheram o assunto ecologia e o tema "descongelamento" da calota polar. No jogo os personagens escolhidos foram os pinguins que devem buscar abrigo. O jogo foi elaborado para que o jogador retirasse os pinguins e fizesse pontuação, retirando o personagem de áreas de risco. Nesse caso o enfoque demonstrou a preocupação em âmbito global, abrangendo questões mais amplas, com relevância e preocupação global. 
A seguir, na Figura 2, está demonstrada a interface do jogo (Scratch) criado pelas alunas $\mathrm{AV}, \mathrm{BL}$ e VC, que problematizaram o assunto "ecologia" e criaram o jogo com personagens (homens) salvando as aves de um incêndio florestal. Nesse jogo, a pontuação indicada esteve diretamente relacionada ao conhecimento da biodiversidade de aves local, salvando-as do fogo e do problema grave, recorrente e temido do clima seco versus queimadas, típico da região e estação do ano.

Figura 2 - Palco, personagens, ações. Interface do jogo criado pelos alunos no Scratch. O personagem precisa se deslocar para salvar as aves do incêndio

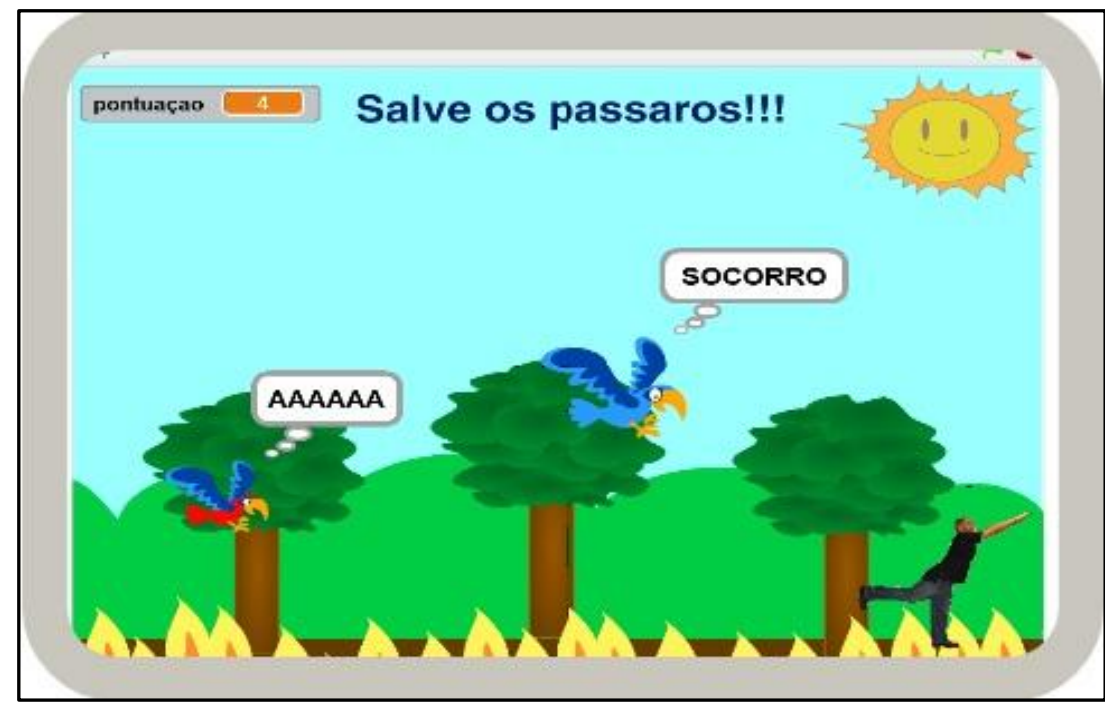

Fonte: O autor (2018)

Na segunda categoria mais importante, "entender/compreender/dificuldades/dúvidas", em que alunos buscaram principalmente o assunto: "genética", para criar os jogos conforme a Figura 3. A aluna A escolheu o tema dentro do assunto genética ${ }^{4}$ e seu jogo foi proposto "porque tenho um pouco de dificuldade e alguns colegas também, e pensei que fazendo um jogo com esse tema seria bom para nosso aprendizado e entendimento do assunto". Nesse relato, percebeu-se que a aluna e seu grupo procuram as tecnologias para ajudar na compreensão dos conceitos. Já o aluno TLM escolheu construir um jogo para entender as fases da mitose. Seu relato segue mesmo sentido da aluna anterior, ou seja, enxergou as tecnologias como ajuda para compreender e sanar suas dúvidas.

$4 \quad$ Quadrado de Punnett 
Figura 3 - Análise das categorias criadas para sumarizar as respostas a questão 2: "por que eu escolhi esse assunto?"

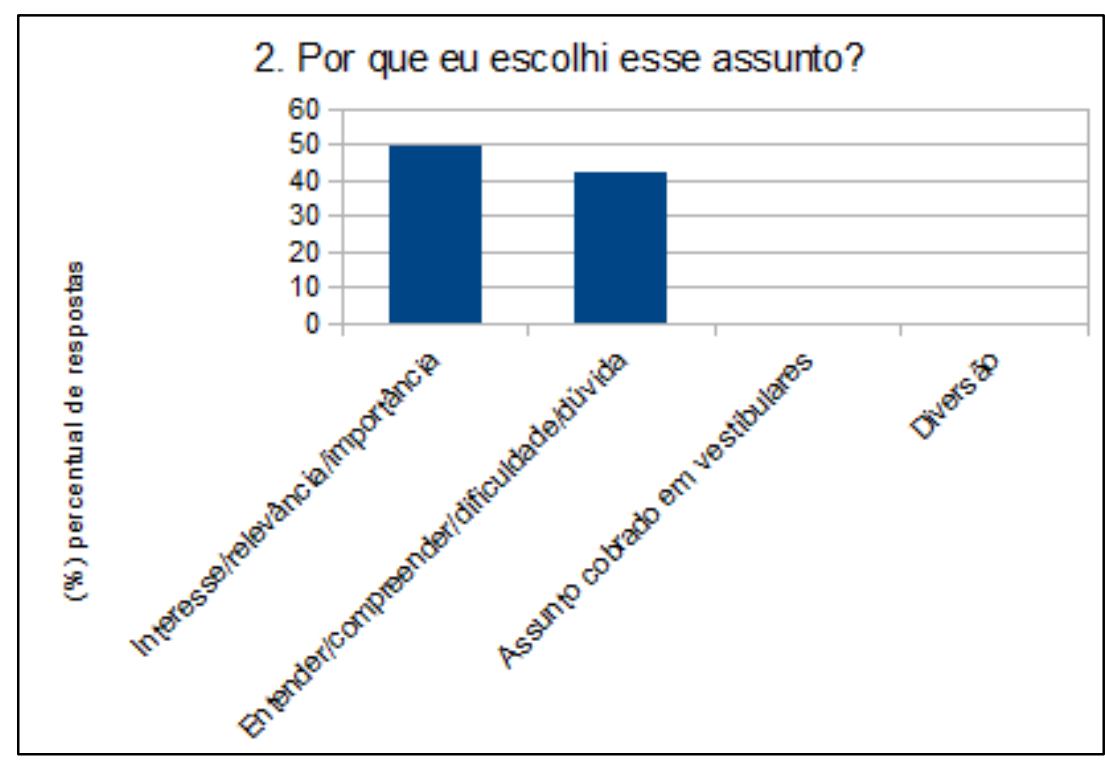

Fonte: $\mathrm{O}$ autor (2018).

As respostas à questão 3 -“Como eu usei o Scratch para tentar encontrar uma solução?" - estimularam a organização do conhecimento, que indicam a articulação entre o problema, a narrativa com cenários e personagens, e o uso das TIC's para elaborar o jogo. Essas respostas refletiram as múltiplas opções de criação de jogos a partir do conhecimento prévio que os adolescentes possuíam sobre as tecnologias e sobre jogos, para, então, construírem suas aprendizagens, associando esse conhecimento, as TIC e interações entre alunos e o professor. Os personagens interagem segundo um contexto pré-criado com a problematização. Optou-se por criar categorias, classificando os tipos de jogos criados pelos alunos, seguindo a indicação de Tarouco et al. (2004): ação, aventura, lógico e estratégicos (Figura 4).

Predominaram os jogos lógicos, do tipo perguntas e respostas, jogos com etapas e interação com o jogador. Os jogos criados do tipo "aventura" enfocaram situações como: ecologia de peixes, incêndio, poluição, em geral com assuntos ligados à ecologia. Em geral os jogos "lógicos" estiveram associados ao assunto: "genética". Observou-se, então, que as estratégias criadas para aprender Biologia e utilizadas com TIC's associaram desafios lógicos com assuntos de maior complexidade e abstração, como a genética. Ao mesmo tempo, as situações mais ligadas ao cotidiano, como o incêndio das matas, por exemplo, os alunos criaram jogos de aventura, com movimento que depende da interação com o jogador. No entanto, destacaram-se ainda jogos com características de mais de um tipo, por exemplo, combinando lógico com estratégia. Nesse tipo de jogo, segundo Tarouco et al. (2004), os alunos deveriam 
aplicar os conhecimentos de sala de aula. Em quase todos houve a aplicação dos conhecimentos devido ao momento inicial de problematização dos assuntos da Biologia e escolha pelos alunos.

Figura 4 - Tipos de jogos criados pelos alunos, segundo categorias determinadas pela análise qualitativa

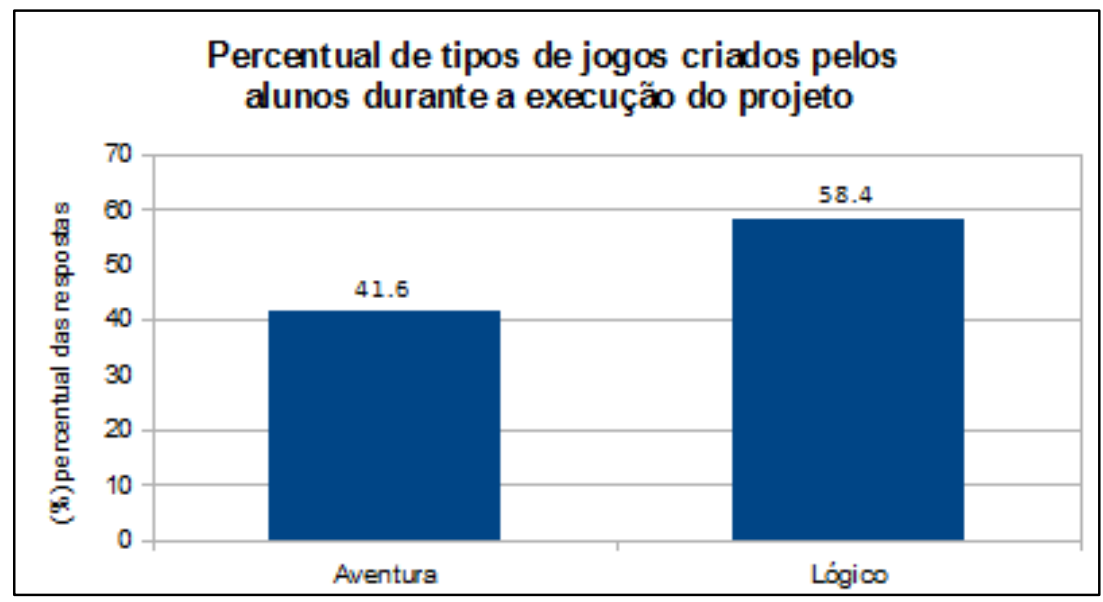

Fonte: $\mathrm{O}$ autor (2018).

Um momento que mereceu destaque nas oficinas e aprendizagens são os relatos dos alunos, evidenciando motivação, como, por exemplo, o depoimento do aluno HH, que diz: Fiz um jogo onde a cadeia alimentar se encaixa, uma ordem de cadeia do maior para o menor, onde um peixe protagonista come peixes menores e morre ao comer peixe maiores (em relação à cadeia alimentar) $[\ldots]^{5}$. Nessa narrativa, percebe-se as características principais do jogo: ordem e regras, interação com o jogador e aplicação dos conceitos de ecologia (cadeia alimentar).

A aluna AC elaborou etapas para a criação de um jogo para entender melhor as fases da mitose e diz: Fiz um jogo com perguntas e respostas e com animações a cada resposta certa você ganha um ponto e a cada resposta errada perde um ponto. O processo de animação e feito a cada resposta, então se você errar o jogo te mostra a resposta correta e em seguida executa a animação te mostrando como é feito o processo. Esse processo de criação ilustra a criação de um jogo de perguntas e respostas, em que o jogador foi desafiado em seu conhecimento a respeito do assunto.

As alunas GGR e TH narraram o tipo de jogo criado para entender a poluição dos mares: Cenário: "Fundo do mar. Atores: Lixos: vidro, galão de óleo e plástico; e ator coletor: Nadador; Roteiro: O lixo vai chegando ao fundo do mar, onde tem um coletor que recolhe o lixo, sendo cada lixo uma pontuação diferente. PLÁSTICO: 3 pontos; VIDRO: 2 pontos;

$5 \quad$ Fonte: questionário avaliador da atividade. 
GALÃO DE ÓLEO: 5 pontos". ${ }^{6} \quad$ Nesse tipo de jogo, observou-se que houve os requisitos acima indicados, porém, o jogo propõe um desafio com escolhas (estratégia) e a pontuação do jogador (escolha e ações) indicou graus diferentes de aplicação do conceito "efeito persistente" do poluente.

A Figura 5 demonstra a interface do jogo criado pela aluna GC, abordando os pares do DNA. Ela explica a criação de seu jogo dessa forma: Há várias letras em azul, e quatro dessas letras são os pares de base do DNA, aperta uma letra e o botão e assim por diante, se a sequência tiver nas sequências de letras do lado esquerdo, a pessoa aperta, se estiver certo a sequência vai começar a piscar de verde.

Figura 5 - Interface capturada de um aluno ao desenvolver o seu jogo no Scratch com o tema "DNA"

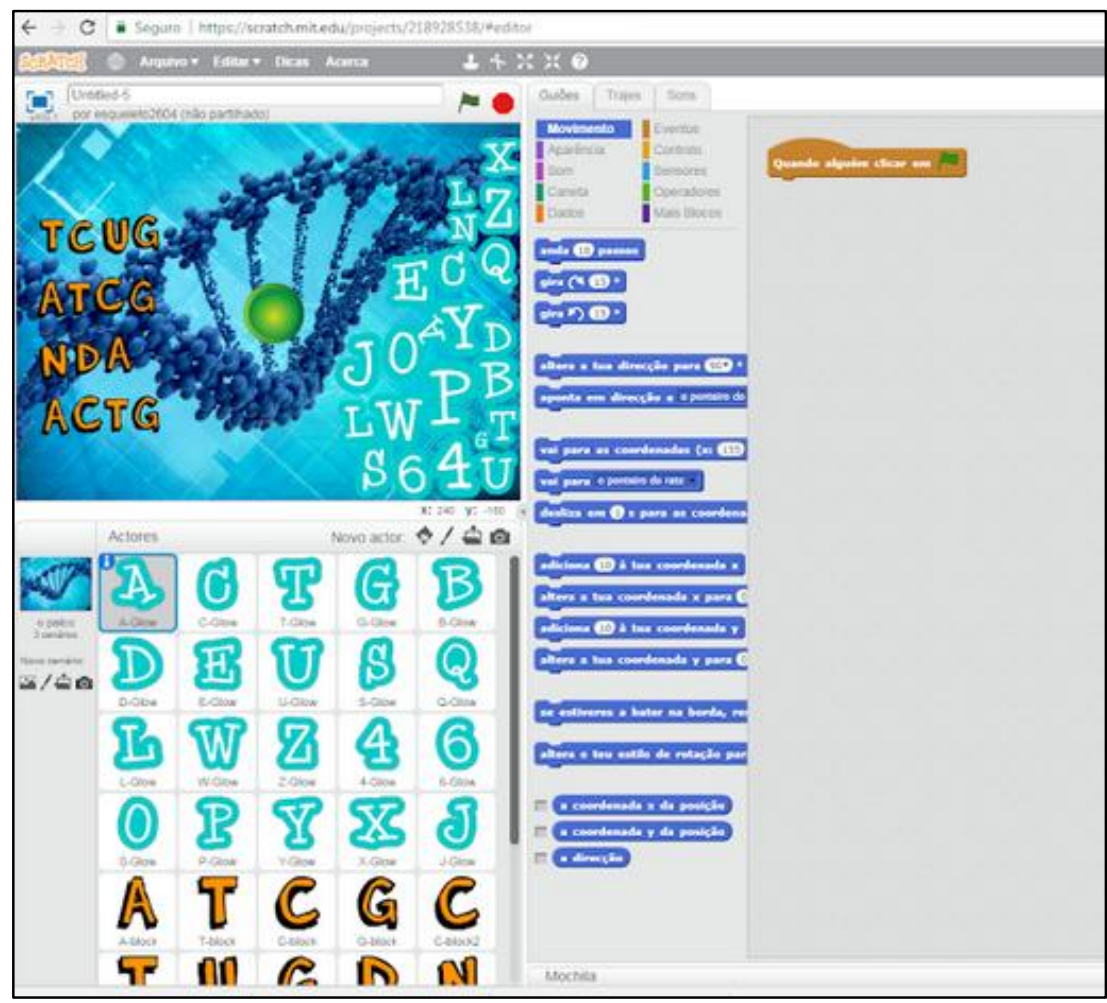

Fonte: O autor (2018).

No gráfico a seguir, demonstrado na Figura 6, observou-se a questão 4 do questionário de avaliação das oficinas, que trata do alcance dos objetivos. Nesse item, a maioria dos alunos $(80,7 \%)$ respondeu que alcançou seus objetivos. As respostas podem servir como uma avaliação inicial do trabalho realizado. Nesse sentido, os alunos que passaram pelas etapas anteriores justificaram a criação dos jogos, a partir das seguintes posições: facilitou o entendimento (aluno 
$\mathrm{HH}$ ); entender melhor o assunto (aluno TLM); pesquisas tiveram que ser feitas [...] creio que tudo o que conseguimos aprender, passamos para os outros (alunas AV, BL e VC); Sim, alcancei porque isso me fez aprender ainda mais sobre o conteúdo e consegui terminar o jogo com tudo o que eu queria fazer (aluno GCM); Nos esforçamos e como resultado aprendemos como funciona (alunos GJ, MV e P). Essa proposta segue os critérios definidos para avaliação de jogos por Savi et al. (2010), combinando os modelos de Kirkpatrick, ARCS e taxonomia de Bloom.

Figura 6 - Frequência percentual das respostas dos alunos a questão 6: "Após a construção do jogo eu acredito

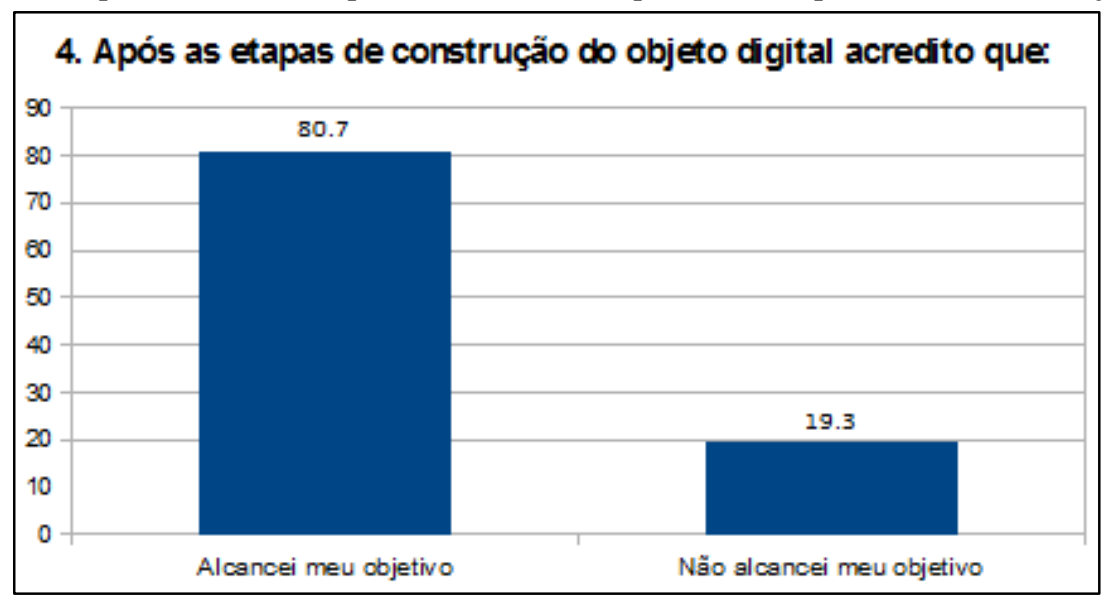

Fonte: O autor (2018).

Por meio dos relatos pode-se perceber que as atividades proporcionaram a construção do "conhecimento" (taxonomia de Bloom), pois os alunos necessitaram de pesquisas para a etapa pedagógica de problematização. Em relação à "compreensão" (taxonomia de Bloom), os alunos demonstraram serem capazes de utilizar a ferramenta para aplicar os conceitos de Biologia em contextos diferentes (Ecologia: degelo, peixes, queimada, poluição; Genética: reprodução celular, quadrado de Punnett, pareamento de bases do DNA).

Entre os tipos de jogos (categorias: análise, síntese e avaliação da taxonomia de Bloom $^{7}$ ), com o auxílio da ferramenta e da mediação entre eles e o professor, foram capazes de combinar personagens, cenários, blocos de programação para criar uma diversidade de tipos de jogos como os de pergunta e resposta, de estratégia, de treinamento (feedback com o jogador), jogos de ação com pontuação. A criação desses jogos demandou manipular conceitos complexos, como "alelos" e "genes", identificar inter-relações (combinações de "alelos" na genética para o descendente, combinar bases nitrogenadas para a fita dupla do DNA), combinar esses 
elementos para formar um todo (a sequência de interações entre jogador e jogo - síntese) e julgar o próprio valor do seu conhecimento (SAVI et al. 2010), quando relataram um ganho no aprendizado a partir da pesquisa e da construção do jogo. Em relação à motivação (modelo ARCS, SAVI et al. 2010), as categorias relevância, confiança e satisfação foram identificadas nos relatos acima. Os alunos declaram que aprendem mais e com satisfação e, com isso, esse sentimento gera confiança que pode influenciar positivamente em seu aprendizado.

Dentre as justificativas dos alunos que não conseguiram alcançar seus objetivos, estão os que relataram dificuldades técnicas e de entendimento do Scratch: Não consegui justamente porque eu não conheço o conteúdo e não consegui formular as perguntas. Além disso, tem a questão técnica de criar o jogo na ferramenta Scratch. Como eu, e acho que muitas pessoas da sala, sabia pouquíssimas técnicas de montagem, devido ao pouco tempo que estudamos o programa, não consegui desenvolver o processo, fazendo com que tudo se tornasse mais difícil e de certa maneira gerasse uma desestimulação (aluno não se identificou). Em relação a essas respostas foi possível identificar que o projeto deveria ter mais tempo para aprender a usar a ferramenta.

Quanto à questão técnica do programa. Pode-se dizer que seria mais ou menos fácil idealizar algum projeto no Scratch, mas se não temos uma base de conhecimento suficiente do programa para realizar o projeto, não me parece possível colocá-lo em ação. Portanto, seria essencial ter um pouco mais de habilidade no programa para concluir um jogo ou algo parecido (relato do aluno GCM).

Houve várias dificuldades durante a execução do projeto. A primeira delas, quanto à elaboração do problema; a segunda, dependia do conhecimento e manipulação da ferramenta, seus blocos, articulação entre as ações dos personagens, entre outras dificuldades.

\section{CONSIDERAÇÕES FINAIS}

Nesta experiência, a aplicação do PAE e a busca por estratégias metodológicas, apoiadas nas TIC, no processo de ensino e aprendizagem, foram ao encontro dos alunos, "nativos digitais" que "respiram e transpiram" tecnologia. Entretanto, o estudo nos mostrou que o êxito, ou seja, atingir os objetivos, depende de uma interação de fatores, exigindo, muitas vezes, alternativas que contemplam a implementação dessas práticas em sala de aula. Ainda, nesse aspecto, depara-se com as limitações de recursos humanos, técnicos e tecnológicos, 
especialmente, nas escolas públicas, além da necessidade de romper algumas barreiras que persistem em relação à inserção das TIC na prática pedagógica.

A partir das expectativas iniciais, propor ao aluno construir a aprendizagem, usar ferramentas digitais para aumentar sua compreensão dos temas relacionados à Biologia, supõese que o presente trabalho trouxe uma experiência importante para reafirmar a necessidade de um ensino modificado, repensando os momentos pedagógicos com a sala de aula mediada pelas TIC's. Ao utilizar as TIC's, os alunos demonstraram que suas capacidades e habilidades podem ser direcionadas para o aprendizado de forma lúdica, com diversão, satisfação e, principalmente, de forma compartilhada.

A principal ferramenta digital utilizada neste trabalho, o Scratch, proporcionou recursos de programação orientada a objetos, no entanto, sem necessitar de uma linguagem de programação de alto nível. Essa característica pode ter auxiliado na ressignificação dos conceitos complexos e na sua construção mediada por essa ferramenta. O nível de abstração dos conceitos pode ser repensado com a construção de novas estratégias para aprender Biologia no nível de ensino médio. De fato, de acordo com os relatos, os alunos demonstraram satisfação durante a execução das atividades propostas.

Os principais avanços identificados com a aplicação do PAE, utilizando o Scratch para construir os jogos digitais, foram: ampliaram-se as possibilidades de aprender pelo interesse e motivação na construção dos jogos; aumentaram a proximidade com a realidade dos alunos, usando as TIC's, que foram fundamentais para a preferência dos alunos; proporcionaram o controle e a autonomia no processo de aprendizagem, pois o aluno, ao usar a TIC e construir o jogo, definiu o ritmo de seu aprendizado; e ainda a disponibilidade e uso das ferramentas disponíveis na rede, onde podem compartilhar e refazer seu processo de aprendizagem.

A partir dos resultados da aplicação do PAE, concluímos que a experiência propiciou a oportunidade de reflexão e o (re)pensar a prática pedagógica na abordagem do ensino e da aprendizagem da Biologia. Desse modo, os recursos utilizados proporcionaram maior compreensão e aplicação dos conceitos na construção dos jogos.

\section{REFERÊNCIAS}

ALVES, Lynn. Relações entre os jogos digitais e aprendizagem: delineando percurso. Portugal, EFT - Educação, Formação \& Tecnologias, v. 1, n. 2, p. 3-10, nov. 2008. Disponível em: <http://eft.educom.pt/index.php/eft/article/view/58/38>. Acesso em: 28 mar. 2018. 
BATTAIOLA, André Luiz. Jogos por computador - histórico, relevância tecnológica e mercadológica, tendências e técnicas de implementação. In: Anais da XIX Jornada de Atualização de Informática, SBC. 2000. v. 2, p. 83-122.

COLL, Cesar; MONEREO, Carlos. Educação e Aprendizagem no século XXI. Novas ferramentas, novos cenários, novas finalidades. In: COLL, César. Psicologia da educação virtual: aprender e ensinar com as tecnologias da informação e da comunicação. Porto Alegre: Artmed, 2010. p. 15-46.

Como entra a cultura digital na escola. 2011. Produzido por educarede. . Disponível em: https://www.youtube.com/watch?v=EAITZRF10bk\&list=PL4E1B0B746C0C854D> . vídeo (3min51s). Acesso em: 27 jun. 2017.

DEMO, Pedro. Educação Hoje: "Novas" tecnologias, pressões e oportunidades. São Paulo: Atlas, 2009.

FAGUNDES, Lea da Cruz; MAÇADA, Débora Laurino; SATO, Luciane Sayuri; Aprendizes do futuro, as inovações começaram. Brasília: MEC, 1999. Disponível em:

<http://www.dominiopublico.gov.br/download/texto/me003153.pdf>. Acesso em: 4 mar. 2017.

FALKENBACH, Gilse A. Morgental. O lúdico e os jogos educacionais. CINTED-UFRGS. Novas Tecnologias na Educação. 2006. Disponível em:

$<$ http://penta3.ufrgs.br/midiasedu/modulo13/etapa1/leituras/arquivos/Leitura_1.pdf>. Acesso em: $1^{\circ}$ jun. 2018.

HUIZINGA, Johan. Homo Ludens. 4.ed. São Paulo: Perspectiva, 2000.

Disponível em: 〈http://jnsilva.ludicum.org/Huizinga_HomoLudens.pdf $>$. Acesso em: 10 jun. 2018.

JUUL, Jesper. A clash between game and narrative. DAC Conference, Bergen, Norway, 1998. Disponível em:

$<$ https://www.jesperjuul.net/text/clash_between_game_and_narrative.html >. Acesso em: 18 jun. 2018.

LALUEZA, José Luis; CAMPS, Isabel Crespo e Silva. As tecnologias da informação e da comunicação e os processos do desenvolvimento e socialização. In: COLL, César. Psicologia da educação virtual: aprender e ensinar com as tecnologias da informação e da comunicação. Porto Alegre: Artmed, 2010. p. 47-65.

LUCCHESE, Fabiano; RIBEIRO, Bruno. Conceituação de jogos digitais. São Paulo, 2009. Disponível em: <www.dca.fee.unicamp.br/ martino/disciplinas/ia369/trabalhos/t1g3.pdf>. Acesso em: 10 jun. 2018.

MATURANA, Humberto. O que é educar? 1995. Disponível em <http://www.dhnet.org.br/direitos/direitosglobais/paradigmas/maturana/oqueeducar.html >. Acesso em: 7 dez. 2017. 
MATURANA, Humberto; DÁVILA, Ximena Paz. Desde la matriz biológica de la existencia humana. Revista PReLac, v. 2, p. 30-39, 2006. Disponível em

$<$ http://unesdoc.unesco.org/images/0014/001455/145502por.pdf\#145872>. Acesso em: 7 jul. 2018.

PRENSKY, Marc. Digital Native, digital immmigrants. Digital Native immigrants. On the horizon, MCB University Press, Vol. 9, N.5, October, 2001. Disponível em:< http://www.marcprensky.com/writing/Prensky\%20\%20Digital\%20Natives,\%20Digital\%20Immigrants\%20-\%20Part1.pdf> . Acesso em: 1 jul. de 2019.

PRENSKY, Marc. Digital game-based learning. Computers in Entertainment (CIE), v. 1, n. 1, p. 21-21, 2003

SANTOS, Jordan Wellington Rodrigues; SILVA, Meyriele Ribeiro da; BENASSI, Vivian Machado; AMARAL, Heber Fernandes. BIOQUIZ: JOGO ELETRÔNICO DE BIOLOGIA PARA O ENSINO MÉDIO. Revista UFG, v. 15, n. 16, 2015. Disponível em: <https://www.revistas.ufg.br/revistaufg/article/view/48532>. Acesso em: 29 maio 2018.

SAVI, Rafael; WANGENHEIM, Cristiane Greese Von; ULBRICHT, Vania; VANZIN, Tarcisio. Proposta de um modelo de avaliação de jogos educacionais. RENOTE- Novas Tecnologias na Educação, Porto Alegre, v. 8, n. 3, 2010. Disponível em < https://www.seer.ufrgs.br/renote/article/view/18043/10630>. Acesso em: 29 jun. 2019.

SILVA, Luciana Aparecida Siqueira; FARIA, Joana Cristina Neves de Menezes. Quiz" da membrana plasmática-construção e avaliação de material didático interativo. Enciclopédia Biosfera, p. 2204-2218, 2012. Disponível em: <http://www.conhecer.org.br/enciclop/2012b/ciencias\%20humanas/quiz.pdf $>$. Acesso em: 29 mai. 2018.

TAROUCO, Liane Margarida Rockenbach; ROLAND, Letícia Coelho; FABRE, MarieChristine Julie Mascarenhas; KONRATH, Mary Lúcia Pedroso. Jogos educacionais. RENOTE - Novas Tecnologias na Educação, Porto Alegre, v. 2, n. 1, p. 1-7, mar. 2004. Disponível em <https://seer.ufrgs.br/renote/article/view/13719/8049>. Acesso em: 29 maio 2018.

Recebido em:15 de abril de 2019. Aprovado em: 29 de junho de 2019. 